\title{
The biomechanical behavior of single crown implant-supported prosthesis with different types of connections and occlusal loads: Photoelastic and strain gauge analysis
}

Comportamento biomecânico de coroa unitária sobre implantes com diferentes tipos de conexões e cargas oclusais: Análise fotoelástica e de extensômetrica

Comportamiento biomecánico de una corona sobre implante con diferentes tipos de conexiones y cargas oclusales: Análisis fotoelástico y de extensometría

Received: 07/07/2021 | Reviewed: 07/14/2021 | Accept: 07/16/2021 | Published: 07/25/2021

Caroline de Freitas Jorge ORCID: https://orcid.org/0000-0001-5372-7164 São Paulo State University, Brazil E-mail: carolinefreitas48@gmail.com

Letícia Cerri Mazza

ORCID: https://orcid.org/0000-0001-6937-472X São Paulo State University, Brazil

E-mail: mazza.leticia@hotmail.com

Marcio Campaner

ORCID: https://orcid.org/0000-0002-8750-0555 São Paulo State University, Brazil E-mail: marciocampaner17@gmail.com

Abbas Zahoui

ORCID: https://orcid.org/0000-0002-2955-8556 University of São Paulo, Brazil E-mail: drabbaszahoui@hotmail.com

Lorena Scaioni Silva

ORCID: https://orcid.org/0000-0002-5370-8323 São Paulo State University, Brazil E-mail: lorenascaioni@gmail.com

Kevin Henrique Cruz

ORCID: https://orcid.org/0000-0001-8669-7707 University Center of Santa Fé do Sul, Brazil E-mail: kevinhcruz@hotmail.com Aldiéris Alves Pesqueira

ORCID: https://orcid.org/0000-0003-3020-5253 São Paulo State University, Brazil E-mail: aldieris.ap@foa.unesp.br

\begin{abstract}
The aim of the study was to evaluate the biomechanical behavior, through photoelastic (PA) and strain gauge analysis (SA), of single crown implant-supported prosthesis with different implant connections (external hexagon (EH), Morse taper (MT), internal Morse hexagon (IMH), Morse taper hexagon (MTH), and frictional Morse taper (FMT)) and different occlusal loads (axial and oblique $\left(45^{\circ}\right)$ ). The data were submitted to ANOVA and Tukey's test $(\alpha=0,05)$. By photoelasticity, regarding axial load, EH produced more high-intensity fringes $(2.784 \mathrm{kPa})$ than the other connections. For the oblique load, all connections generated the same high-intensity fringes ( $3.480 \mathrm{kPa})$, except by MT group, that produced the same amount as axial load $(2.088 \mathrm{kPa})$. For the strain gauge analysis, for the axial load, EH showed the highest microstrains value $(158,76)$ and lowets for MT $(59,88)$. For all other groups, oblique load produced higher microstrains values than axial load. For the oblique load, MT showed the lowest microstrains value (88.79), followed by FMT $(391,43)$, EH $(468,47)$ and IMH $(507,65)$. MTH presented the highest value $(621,25)$ compared to all groups $(\mathrm{P}<0.05)$. When comparing both loads of the same connection system, only MT showed similar values $(\mathrm{P}<0.05)$. It was possible to conclude that the different connection systems tested directly influenced the stress distribution at both loads. The implants with internal connection present less stress distribution when submitted to axial load than the EH group. However, when the oblique load was applied, all connections presented higher values of stress distribution, except for the MT group.
\end{abstract}

Keywords: Dental implants, Prostheses and implants, Dental implant-abutment design. 


\begin{abstract}
Resumo
O estudo avaliou por análise fotoelástica (PA) e extensômetrica (SA), a distribuição de tensão em coroa unitária implanto suportada com diferentes tipos de conexão de implantes (Hexagono externo (EH), Cone morse (MT), Hexagono interno morse (IMH), cone morse hexagonal (MTH) e cone morse friccional (FMT) em diferentes cargas oclusais (axial e obliqua $\left(45^{\circ}\right)$ ). Os dados foram submetidos a ANOVA e teste Tukey $(\alpha=0,05)$. Para fotoelásticidade, para a carga axial, EH teve maior intensidade de franjas $(2.784 \mathrm{kPa})$. Para carga obliqua, todas as connexões geraram a mesma quantidade de franjas de alta intensidade $(3.480 \mathrm{kPa})$, menos o grupo MT, que produziu a mesma quantidade que a carga axial (2.088 kPa). Para a análise extensométrica, para a carga axial, EH mostrou maiores valores de microstrains $(158,76)$ e o menor foi MT $(59,88)$. Para todos os grupos, a carga obliqua produziu maiores valores de microstrain do que a carga axial. Para carga obliqua, MT apresentou menores valores de microstrains (88.79), seguido por FMT (391,43), EH (468.47) e IMH (507.65). MTH apresentou maiores valores $(621,25)$ comparando todos os grupo $(\mathrm{p}<0,05)$. Comparando as cargas no mesmo Sistema de conexão, somente MT apresentou valores similares $(\mathrm{P}<0,05)$. Com isso pode concluir que diferentes sistemas de conexão influenciaram diretamente na distribuição de tensão. Os implantes com conexão interna apresentam menor distribuição de tensões quando submetidos à carga axial do que o grupo EH. Porém, quando a carga oblíqua foi aplicada, todas as ligações apresentaram maiores valores de distribuição de tensões, exceto para o grupo MT.
\end{abstract}

Palavras-chave: Implantes dentários; Próteses e implantes; Projeto do implante dentário-pivô.

\title{
Resumen
}

El estudio evaluó mediante análisis fotoelástico (PA) y de extensometría (SA), la distribución de tensiones en una corona implantosoportada con diferentes tipos de conexión de implante (Hexágono externo (EH), Cono Morse (MT), Hexágono interno morse (IMH), Cono morse hexagonal (MTH) y Cono morse friccional (FMT) a diferentes cargas oclusales (axial y oblicua (45o)). Los datos fueron sometidos a ANOVA y a la prueba de Tukey $(\alpha=0.05)$. Para fotoelasticidad, con relación a la carga axial, EH tuvo mayor intensidad de franjas $(2.784 \mathrm{kPa})$. Para la carga oblicua, todas las conexiones generaron la misma cantidad de franjas de alta intensidad $(3.480 \mathrm{kPa})$, menos el grupo MT, que produjo la misma cantidad que la carga axial $(2.088 \mathrm{kPa})$ Para el análisis de extensometría, en relación con la carga axial, EH mostró valores de microstrain más altos $(158,76)$ y el más bajo fue para MT $(59,88)$. Para todos los grupos, la carga oblicua produjo valores más altos de microstrain que la carga axial. Para la carga oblicua, MT tuvo valores de microstrain más bajos (88.79), seguido de FMT (391,43), EH (468.47) e IMH (507.65). MTH tuvo valores más altos $(621,25)$, comparando todos los grupos ( $\mathrm{p}<0,05)$. Comparando las cargas en un mismo Sistema de Conexión, solo MT presentó valores similares $(\mathrm{P}<0.05)$. Por lo tanto, se puede concluir que diferentes sistemas de conexión influyeron directamente en la distribución de tensiones. Los implantes con conexión interna presentaron una distribución de tensiones más baja, cuando sometidos a la carga axial, que el grupo EH. Sin embargo, cuando se aplicó la carga oblicua, todas las conexiones presentaron los valores más altos de distribución de tensiones, excepto el grupo MT.

Palabras clave: Implantes dentales; Prótesis e implantes; Diseño de implante dental-pilar.

\section{Introduction}

The oral rehabilitation with dental osseointegrated implants are widely used nowadays, and provides elevate success rates in prosthetics restorations of partial and total edentulous patients (Goiato et al.,2013; Goiato et al.,2009; Schmitt et al.,2014). Among the several factors that influence the success of rehabilitation, there is the biomechanics, which directly influences the maintenance of marginal bone quality (Schmitt et al., 2014; Cooper et al., 2016). This factor is related to some aspects such as implant geometry, surface, size, diameter, connection design, position, angulation, abutment and quantity and direction of the load applied to the restoration (Schmitt et al., 2014; Cooper et al., 2016). The proper adaptation of the implant-abutment and prosthesis interface have an important role in the stability of the whole assembly (Goiato et al., 2013; Goiato et al.,2009; Schmitt et al.,2014). In addition, it was discovered that the implant designs and abutment utilized, directly influence the stress distribution to the marginal bone (Schmitt et al.,2014; Cooper et al., 2016; Gracis et al., 2012; Nishioka et al., 2011; Lemos et al., 2018).

The first design of connection of implants, developed by Branemark and introduced to scientific community, was the external hexagon (EH)(Gracis et al., 2012, Breemark et al., 1985), been used for longer than the internal connections. However, it is known that this design of connection has some limitations and disadvantages when compared to the internal connections, having more complications in the screw and abutment regions (Schmitt et al., 2014; Cooper et al., 2016; Gracis et al., 2012).

After the external connection, internal connections have been introduced to the market, and more types of designs have emerged, in order to improve the distribution of implant / bone stress (Gracis et al., 2012, Lemos et al., 2018). These connections have varied designs, such as: internal hexagons and octagons, conical (Morse taper - MT), frictional or a combination of these 
designs (Goiato et al.,2013; Goiato et al.,2009; Gracis et al., 2012). The internal connections have shown better stress distribution, being the stress distributed more apically and not in the region of marginal bone, and less number of screw loss have been reported( Goiato et al.,2013; Schmitt et al., 2014). MT connections also presents elements of stabilization, such as better locking of the abutment and the presence of anti-rotation hexagon (Schmitt et al., 2014, Yamaguchi et al., 2017). Besides the excellent mechanical stability, proven by in vitro studies (Finger et al., 2003; Maeda et al., 2006) and longitudinal clinical trials (Astrand et al., 2004; Nentwig et al., 2004), MT implants, with platform switching concept, have shown better stress distribution than implants with external connections (Atieh et al., 2010).

Another factor to be considered is the different occlusal forces, in which the implants are submitted. These forces significantly influence the micro movement of the implant and, consequently, the osseointegration and marginal bone remodeling (Campaner et al. 2019). It was reported that both axial and oblique loading conditions are capable to influence implant mobility (Goellner et al., 2011).

There are several studies (Goiato et al., 2012; Goiato et al., 2009; Assunção et al., 2009) that evaluated the performance of the bone tissue in the regions surrounding the implants. Among them, the photoelastic analysis stands out (Goiato et al., 2012; Goiato et al., 2009; Assunção et al., 2009; Zaparolli et al.,2017) and the strain gauge analysis (Campaner et al., 2019; Ozcelik et al., 2007). It is important to emphasize that none of the analyzes have complete preponderance over another, (Goiato et al., 2009) resulting in a consensus among researchers that the analyses complement each other's use together in their studies.

The aim of the study was to evaluate the biomechanical behavior, through photoelastic (PA) and strain gauge analysis (SA), of single crown implant-supported prosthesis with different implant connections (external hexagon (EH), Morse taper (MT), internal Morse hexagon (IMH), Morse taper hexagon (MTH), and frictional Morse taper (FMT)) and different types of occlusal loads (axial and oblique). The null hypothesis of this study was that the different systems of internal connections would not present difference in the distribution of stress when compared to the external connection.Use the paragraph as a template.

\section{Methodology}

\section{Study design}

For this study, 30 models were fabricated: five for photoelastic analysis $(n=1)$ and 25 for strain gauge analysis $(n=5)$. One implant of 11,5x4mm (DSP Biomedical) was used for each group, according to the connection system (Table 1) and for each group one single crown implant-supported prosthesis was fabricated. All models were evaluated through axial and oblique forces in a universal testing machine (Figure 1).

Figure 1. Study design (connections used in the study; sample models of photoelastic analysis and sample models of strain gauge analysis; load of $100 \mathrm{~N}$ in the axial direction and $50 \mathrm{~N}$ in the oblique direction).

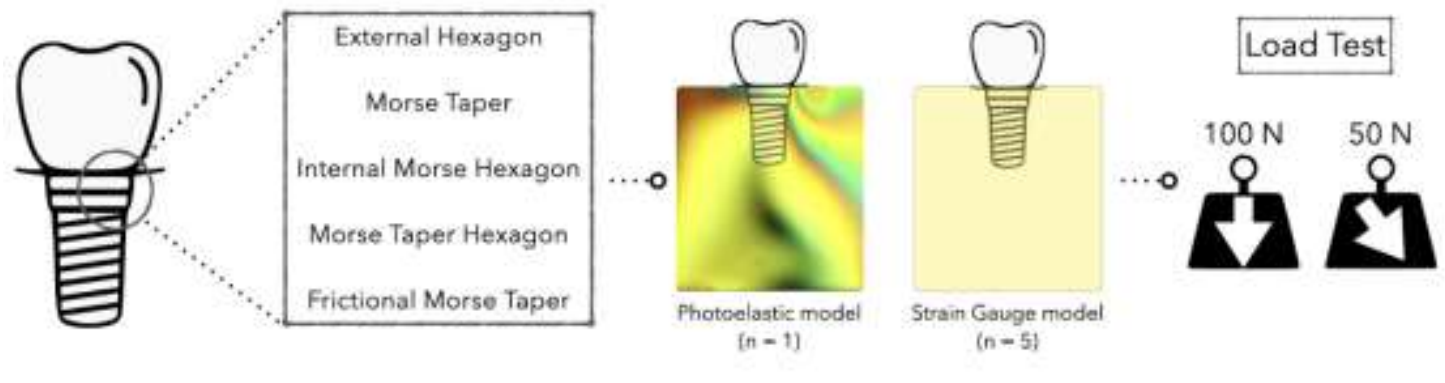

Source: Authors. 


\section{Models fabrication}

Initially, a metal matrix (10x30x45 mm) was duplicated using a silicone polymer in order to obtain a mold in special type IV gypsum (Dentsply). Subsequently, the gypsum models were drilled to receive an analog (DSP Biomedical) corresponding to each group, then this analog was connected with its respective square transfer (DSP Biomedical).

Silicone polymer was again used to obtain an impression of the cast for the preparation of the photoelastic and polyurethane casts. After the silicone polymerization, the transfer screw was unscrewed and removed to permit the plaster cast removal from the cast without moving the transfer position. Thus, the silicone matrix with the transfer already positioned was obtained, beginning with those which were attached to the implants (DSP Biomedical) from each group, according to the specifications of each (Table 1) through the help of hemostatic forceps (Campaner et al., 2019).

Table 1: Division of tested groups.

\begin{tabular}{cccc}
\hline Groups & Connections systems & Dimensions & Abutment \\
\hline EH & External Hexagon & $11.5 \times 4 \mathrm{~mm}$ & Flexcone \\
\hline MT & Morse Taper & $11.5 \times 4 \mathrm{~mm}$ & Flexcone \\
\hline IMH & Internal Morse Hexagon & $11.5 \times 4 \mathrm{~mm}$ & Flexcone \\
\hline MTH & Morse Taper Hexagon & $11.5 \times 4 \mathrm{~mm}$ & Flexcone \\
\hline FMT & Frictional Morse Taper & $11.5 \times 4 \mathrm{~mm}$ & Flexcone \\
\hline
\end{tabular}

Source: Authors.

Initially, the silicone matrixes described above were used for the fabrication of five photoelastic models. For this, the photoelastic resin (PL-2, Vishay, Micro-Measurements Group) was manipulated according to the manufacturer's instructions and inserted into the silicone cast with the implants (Goiato et al., 2013; Goiato et al., 2009; Campaner et al., 2019). The assembly was submitted to a $40 \mathrm{lbf} /$ pol 2 pressure to remove internal bubbles. The photoelastic model was separated from the silicone cast after polymerization and polished with fine-grit abrasive paper of different granulations \#300, \#400, \#600 and \#1200 (Buehler).

Five specimens were fabricated for each group for the strain gauge analysis. The same silicon previously described was used, where the respective implants were positioned and later filled with the F160 polyurethane resin (F160 Axson Brazil).

\section{Photoelastic analysis}

The model was positioned in a glass container with vegetable oil, and a polariscope (PS-100 SF Standard Field Polarimeter, Strainoptics, Inc., North Wales, PA, USA) was used to monitor the isochromatic fringes. The images were recorded by a digital camera (EOS Rebel T6I, Canon, Tokyo, Japan), these images were recorded after the models received the total load of $100 \mathrm{~N}$ in the axial direction and $50 \mathrm{~N}$ in the oblique direction with a universal testing machine (EMIC-DL 3000). The fringes were analyzed in the images with the help of a software (AdobePhothoshop CS3).

When bigger the number of fringes with variation between pink-green, the higher the magnitude of tension, and when closer the fringes to each other, the higher the concentration of stresses (Goiato et al., 2013, Zaparoli et al., 2017). In order to facilitate the concentration of tension analyze, the implant region was divided into three regions: cervical, middle and apical third. The tensions' values were calculated in accordance with the study of Zaparolli et al. 2017, in which values of tension were given to each fringe order as described in Table 2. 
Table 2. Fringe order and the corresponding stress value, (transition between green/pink $=696 \mathrm{kPa})(18)$.

\begin{tabular}{l|l}
\multicolumn{1}{c|}{ Fringe order } & \multicolumn{1}{c}{ Stress Value } \\
\hline $\mathbf{0}$ (black) & $0 \mathrm{kPa}$ \\
\hline $\mathbf{1}$ (violet/blue transition) & $232 \mathrm{kPa}$ \\
\hline $\mathbf{2}$ (purple/blue transition) & $464 \mathrm{kPa}$ \\
\hline $\mathbf{3}$ (red/green transition) & $696 \mathrm{kPa}$ \\
\hline
\end{tabular}

Source: Authors.

\section{Strain gauge analysis}

Two strain gauge were placed and bonded in the polyurethane model, in the mesial and distal region of each implant (Figure 2). The strain gauges were configured into a one-quarter Wheatstone bridge, and the tinned ends of the copper wires from the strain gauges were welded in a T-50 bondable terminal. Subsequently, these were to shielded flexible cables and connected to inputs of a data acquisition system (ASD 2000; Lynx Tecnologia Eletronica Ltda). The load of $100 \mathrm{~N}$ in the axial direction and 50 $\mathrm{N}$ in the oblique direction was applied five times in the prostheses of each group and the values of stress (microstrains) were recorded by using the data acquisition system.

Figure 2. Strain gauge placed and bonded in the polyurethane model, in the mesial and distal region.

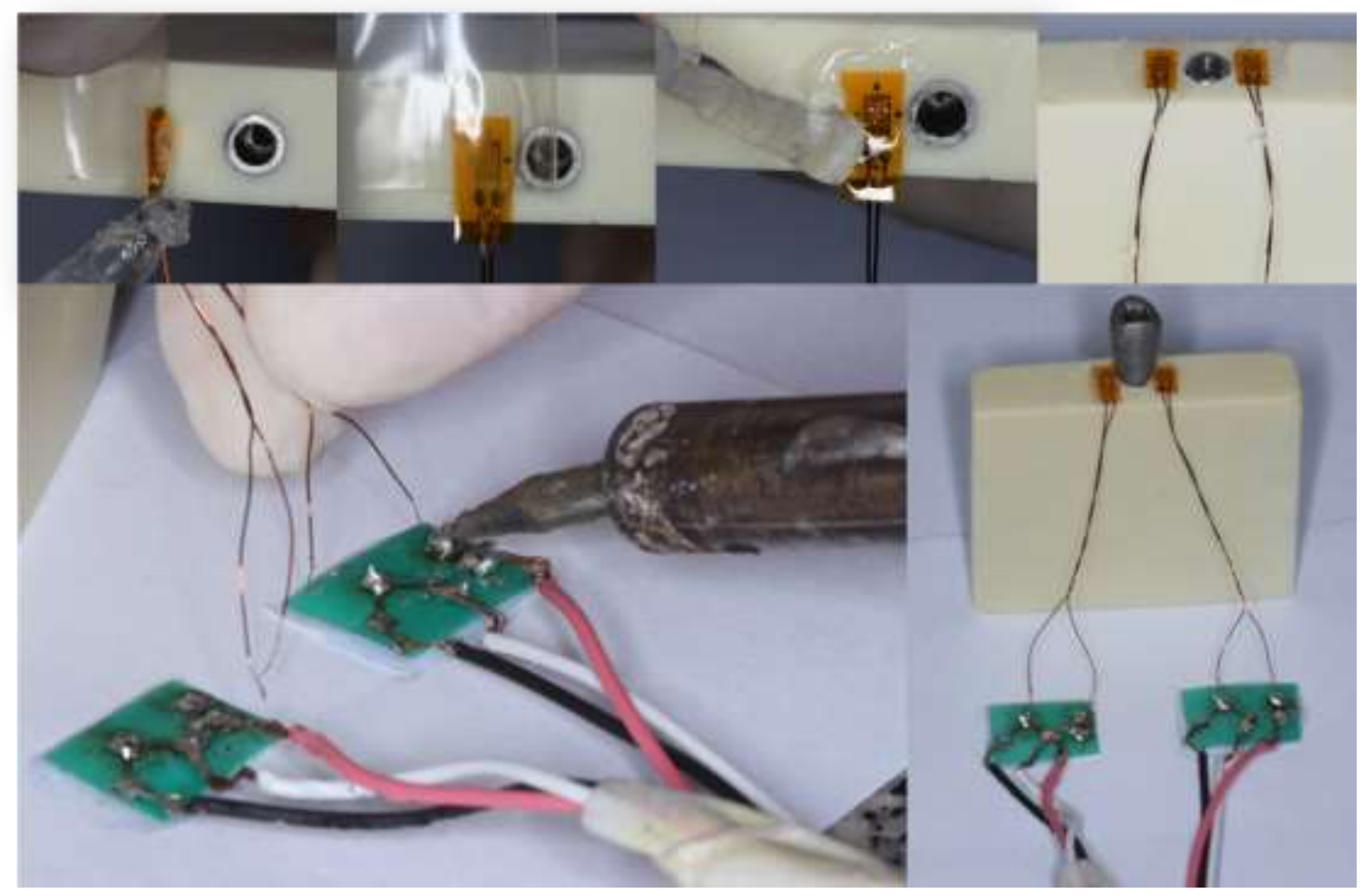

Source: Authors.

\section{Statistical analysis}

For the statistical analysis, the one-way Analysis of Variance (1-way ANOVA) was performed, followed by the Turkey HSD test. Statistical software (SPSS version 20.0 - Statistical Package for the Social Sciences, IBM Corporation, Armonk, NY, USA) was used, and all tests were conducted at a significance level of $5 \%$. 


\section{Results and Discussion}

\section{Results}

Figures 3,4 e 5 shows the results of photoelastic analysis. Comparing the loads of each connection system, oblique load generated more high-intensity fringes than axial load for all groups, except for the MT group that the amount was equal. Regarding axial load, EH produced more high-intensity fringes $(2.784 \mathrm{kPa})$ than the other connections $(<3)$. For the oblique load, all connections generated the same high-intensity fringes $(3.480 \mathrm{kPa})$, except by MT group, that produced the same amount as axial load $(2.088 \mathrm{kPa})$.
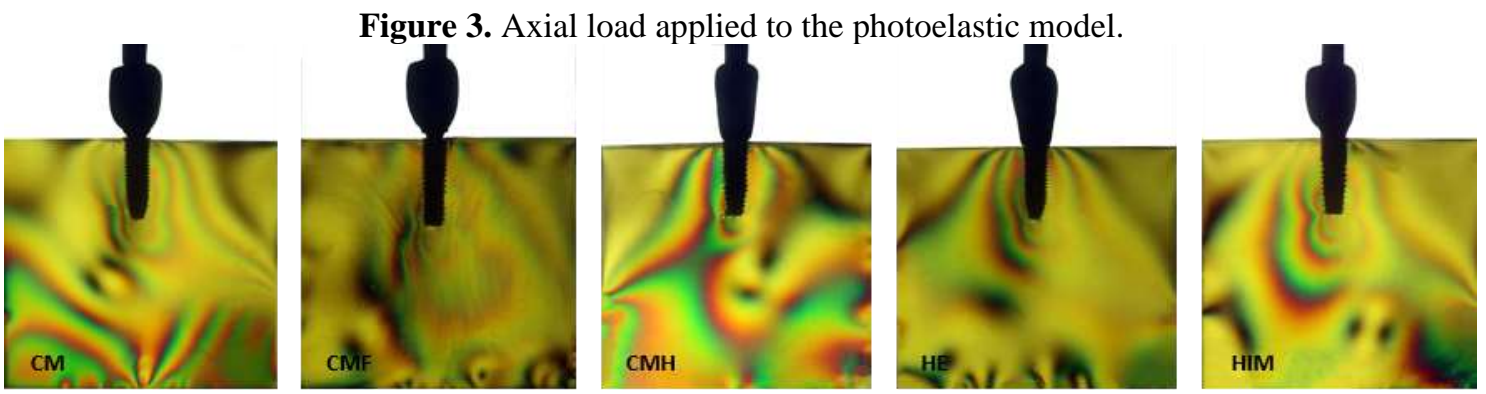

Source: Authors.

Figure 4. Oblique load applied to the photoelastic model.
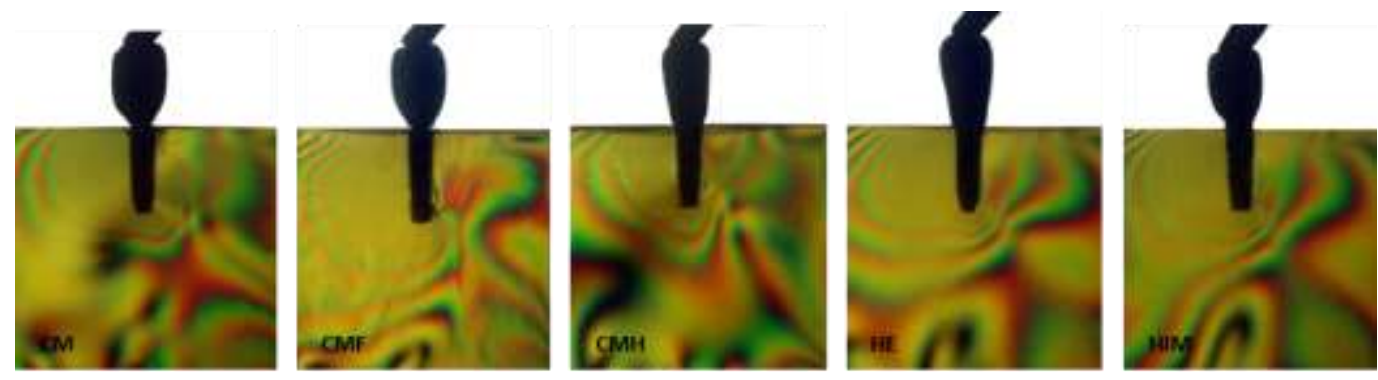

Source: Authors.

Figure 5. Photoelastic analysis: quantity of high-intensity fringes (pink-green transition) according to connection systems.

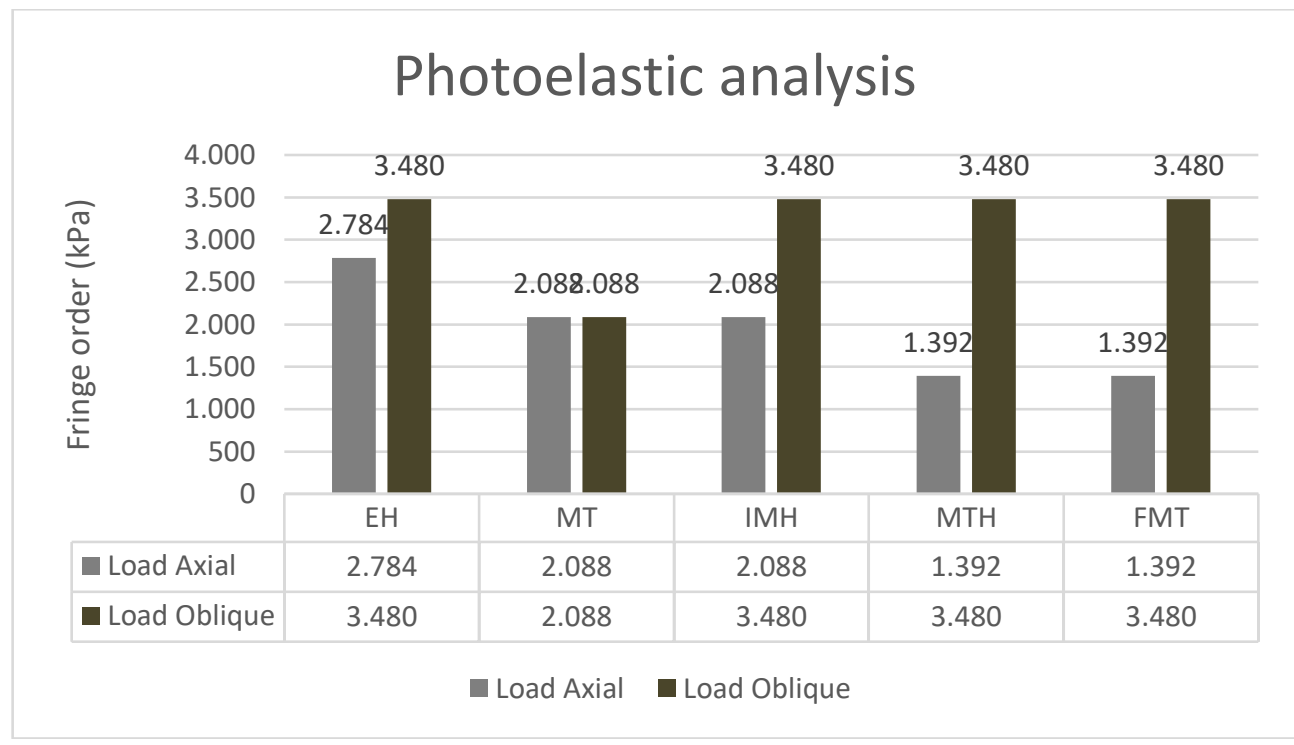

Source: Authors. 
In the strain gauge analysis, all factors influenced the factors evaluated (Table 3). For the axial load, EH showed the highest microstrain value (159 microstrains) compared to all the internal connections (MT:80, IMH:81, MTH:94, FMT:60). For the oblique

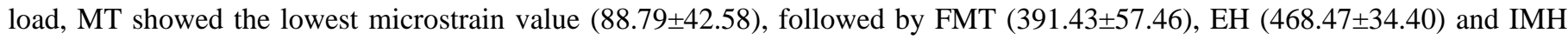
(507.65 \pm 25.22$)$. MTH presented the highest value (621.25 \pm 72.14$)$ compared to all groups (P <0.05) (Figure 6). When comparing both loads of the same connection system, only MT showed similar values $(\mathrm{P}<0.05)$. For all other groups, oblique load produced higher microstrains values than axial load.

Table 3: Analysis of Variance (ANOVA) with comparison between types of connection in implant-supported prostheses subjected to axial and oblique loads.

\begin{tabular}{lccccc}
\hline Variance Factors & SS & $d f$ & MS & F & $P$ \\
\hline Connections & 454870.276 & 4 & 113717.569 & 86.483 & $<.001^{*}$ \\
Load & 1285614.355 & 1 & 1285614.355 & 977.715 & $<.001^{*}$ \\
Connection*Load & 378467.215 & 4 & 94616.804 & 71.956 & $<.001^{*}$ \\
Error & 52596.693 & 40 & 1314.917 & & \\
Total & 5427157.631 & 50 & & & \\
\hline
\end{tabular}

$* \mathrm{P}<0.05$ denotes statistically significant difference. Source: Authors.

Figure 6. Mean values (standard deviation) of microstrains of connection type in implant-supported prostheses subjected to axial and oblique loads. Means followed by the same uppercase letter in the column (different connection type with the same load) and lowercase in the row (the same connection type with the different loads) do not differ at the $5 \%$ level of significance (P <0.05) by the Tukey test.

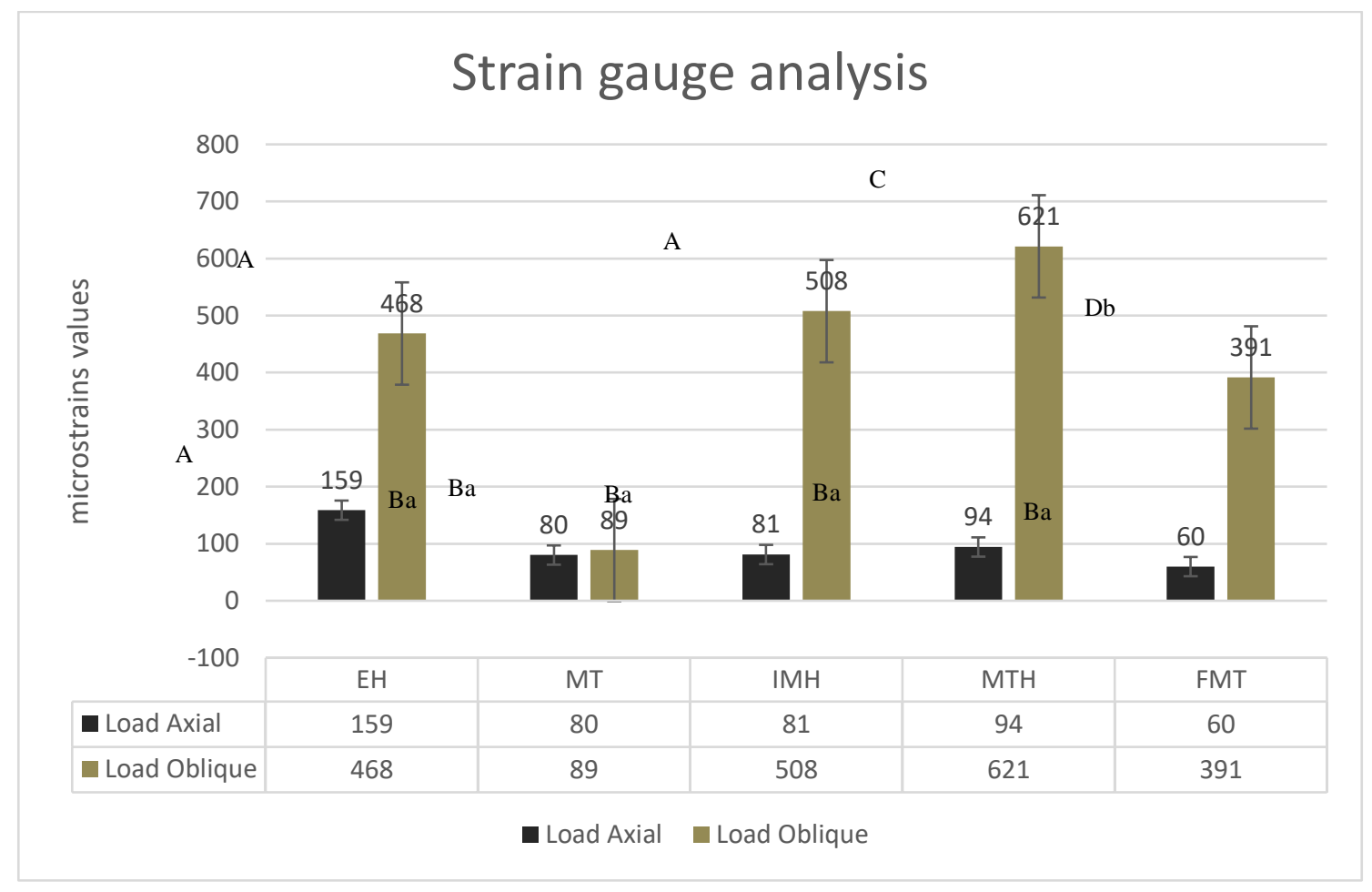

Source: Authors. 


\section{Discussion}

The results indicated that internal connections, especially Morse Taper, showed lower stress surrounding the implants than external connections, thus, the null hypothesis of this study was rejected. All connections presented more stress around the implant when oblique load was applied, in both analysis, except in the MT group. The photoelastic analysis showed similar number of fringes for both loadings evaluated of MT group and, in the strain gauge analysis, this group presented the lowest values with statistical difference compared to all other connections $(\mathrm{P}<0.05)$.

Through the photoelastic analysis, it is possible to verify the formation of stress induced in the prosthesis/implant/bone system (Goiato et al., 2012, Campaner et al., 2019). It is possible to simulate and analyze the mechanical conditions existing in this kind of rehabilitation, due to direct visualization of the distribution of stress (Goiato et al., 2012, Pesqueira et al., 2014). In this technique, the location of the tensions within an experimental model is observed through fringes of different colorations (Goiato et al., 2012; Pesqueira et al., 2014; Koke et al., 2004). It allows a qualitative evaluation of deformation of a stressed area in the comparison of an area free of stress (Goiato et al., 2012). Thus, the lower number of high-intensity fringes around the implants with internal connections is due to the fact that they present greater stress centralization throughout the implant (Cehreli et al., 2004), the different biomechanical behavior of this implant offers a more extended lateral union wall of the abutment against the implant`s internal wall (Pessoa et al., 2010).

In the strain gauge analysis, it is possible to evaluate the analysis on prostheses, implants and teeth, both in vivo and in vitro situations (Goiato et al., 2012; Binon et al., 2000). This analysis generates quantitative data of tension in the area where the extensometer is positioned (Goiato et al., 2012; Campaner et al., 2019). In the application of axial load in the present study, the EH group presented the highest stress values compared to the implants with internal connection. In the study by Binon et. Al., 2000, the authors found that internal connections presented intimate contact between the internal region of the implant and the external region of the abutment, which is beneficial for load distribution and retention of the screw. However, when the load application was oblique, all groups significantly increased their values, except for the MT group. This is in agreement with the results of Aunmeungtong et. Al., 2016, in which the application of the oblique load on the implants caused an average stress and strain 2-4 times higher than that caused by axial loading. This increase in tension values is caused by the increase in the force distribution angle that generates higher stress values at the bone-implant interface (Goellner et al., 2011).

In a systematic review comparing external and internal connections, they found that the types of connections influence the magnitude of bone loss. The results indicated that internal connection implants were associated with less bone loss than the external connection implants (Lemos et al., 2017). In our study, the IMH group when applying axial loads also had results close to the MT group. Palmer et al., 1997 did not observe cases of loosening of screws in internal hexagon implants. Besides that, attested that these connections are successful and their bone loss marginal, in the first 2 years is comparable to other systems that report high lonf-term success.

In a randomized, controlled, split month and clinical trial (Pessoa et al., 2017) compared bone remodeling around implants with connections external hexagon and morse taper. Implants with connections morse taper showed less crestal bone changes, compared to external hexagon. One of the reasons, may be due to the difference in absorption of lateral loads. While, the external hexagon determine the rotation position, but does not absorb the lateral load, the morse taper is able to prevent lateral loads manly by the conical interface, which prevents the abutment from tilting off (Pessoa et al., 2017, Pessoa et al., 2010).

Emphasizing, that the crestal bone changes found in external hexagon connections are the result of high values of tension around the implant, which causes micro-movements of the abutment, resulting in microgaps and thus, inflammation of the periimplant issue (Pessoa et al., 2017; Carvalho et al., 2016). Thus, by promoting less tension around the implant, the morse taper connection contributes to greater bone prevention (Andrade et al., 2016). These report justify with the values found in this study, in which the MT group demonstrate lower tension values. 
As this in an in vitro study, there are some limitations, such as fluctuations in the values of masticatory loads in intraoral, prosthetic crowns can be manufactured from different materials interfering in the dissipation of tensions and mainly differences in the design of implants depending of their manufacturer. Therefore, further studies are needed to better assess the influence of masticatory loads, such as mastication simulators and to add more implant manufacturers. Thus, better predictability in the distribution of loads and providing the clinician more secretly in choosing a system that presents less damage.

\section{Conclusion}

Based on the results and considering the limitations of study, it was concluded that:

- The different connection systems tested directly influenced the stress distribution at both loads.

- The implants with internal connection present less stress distribution when submitted to axial load than the EH group. However, when the oblique load was applied, all connections presented higher values of stress distribution, except for the MT group.

\section{Acknowledgments}

Pró-Reitoria de Pós-Graduação e Pesquisa da UNESP (PROPe) - Programa Ações Afirmativas - (Processo no 33501 )

\section{References}

Andrade, C. L., Carvalho, M. A., Cury, A. A. D. B., \& Sotto-Maior, B. S. (2016). Biomechanical Effect of Prosthetic Connection and Implant Body Shape in LowQuality Bone of Maxillary Posterior Single Implant-Supported Restorations. The International journal of oral \& maxillofacial implants, 31(4), 92-7.

Assuncao, W. G., Barao, V. A. R., Tabata, L. F., Gomes, E. A., Delben, J. A., \& dos Santos, P. H. (2009). Biomechanics studies in dentistry: bioengineering applied in oral implantology. J Craniofac Surg, 20, 1173-7.

Astrand, P., Engquist, B., Dahlgren, S., Grondahl, K., Engquist, E., \& Feldmann, H. (2004) Astra Tech and Branemark system implants: a 5-year prospective study of marginal bone reactions. Clin Oral Implants Res, 15, 413-20.

Atieh, M. A., Ibrahim, H. M., \& Atieh, A. H. (2010). Platform switching for marginal bone preservation around dental implants: a systematic review and metaanalysis. J Periodontol, 81, 1350-66.

Aunmeungtong, W., khongkhunthian, P., \& Rungsiyakull, P. (2016). Stress and strain distribution in three different mini dental implant designs using in implant retained overdenture: a finite element analysis study. ORAL \& implantology, 9(4), 202-212.

Binon, P. P. (2000). Implants and components: entering the new millennium. Int J Oral Maxillofac Implants, (15), 76-94.

Branemark, P. I., Zarb, G., Albrektsson T. \& Rosen, H. (1986). Tissue-Integrated Prostheses. Osseointegration in Clinical Dentistry. Quintessence Publishing Co. Plastic and Reconstructive Surgery, 77(3), 496-497.

Campaner, M., Borges, A. C. M., Camargo, D. A., Mazza, L. C., Bitencourt, S. B., Medeiros, R. A., Goiato, M. C., \& Pesqueira, A. A. (2019). Journal of Clinical \& Diagnostic Research, 13(5), 04-09.

Cehreli, M. C., Akca, K., Iplikcioglu, H., \& Sahin, S. (2004). Dynamic fatigue resistance of implant-abutment junction in an internally notched morse-taper oral implant: influence of abutment design. Clin Oral Implants Res, 15, 459-65.

Cooper, L. F., Tarnow, D., Froum, S., Moriarty, J., \& De Kok, I. J. (2016). Comparison of Marginal Bone Changes with Internal Conus and External Hexagon Design Implant Systems: A Prospective, Randomized Study. Int J Periodontics Restorative Dent, 36, 631-42.

Finger, I. M., Castellon, P., Block, M., \& Elian, N. (2003). The evolution of external and internal implant/abutment connections. Pract Proced Aesthet Dent, 15, 625-32.

Goellner, M., Schmitt, J., Karl, M., Wichmann, M., \& Holst, S. (2011). The effect of axial and oblique loading on the micromovement of dental implants. International Journal of Oral \& Maxillofacial Implants, 26(2), 257-64.

Goellner, M., Schmitt, J., Karl, M., Wichmann, M., \& Holst, S. (2011). The effect of axial and oblique loading on the micromovement of dental implants. International Journal of Oral \& Maxillofacial Implants, 26(2), 257-64.

Goiato, M. C., Pesqueira, A. A., Falcon-Antenucci, R. M., Dos Santos, D. M., Haddad, M. F., Bannwart, L. C., \& Moreno A. (2013). Stress distribution in implantsupported prosthesis with external and internal implant-abutment connections. Acta Odontol Scand, 71, 283-8.

Goiato, M. C., Tonella, B. P., Ribeiro, P. P., Ferrac, R., \& Peliizzer, E. P. (2009). Methods used for assessing stresses in bucomaxillary prostheses: photoelasticity, finite elemento technique and extensometry. J Craniofac Surg, 20, 561-4. 
Gracis, S., Michalakis, K., Vigolo, P., Vult von Steyern, P., Zwahlen, M., \& Sailer, I. (2012). Internal vs. external connections for abutments/reconstructions: a systematic review. Clin Oral Implants Res, 23, 202-16.

Koke U, Wolf A, Lenz P, \& Gilde H. (2004). In vitro investigation of marginal accuracy of implant-supported screw-retained partial dentures. J Oral Rehabil, 31, 477-82.

Lemos, C. A. A., Verri, F. R., Bonfante, E. A., Santiago Junior, J. F., \& Pellizzer, E. P. (2017). Comparison of external and internal implant-abutment connections for implant supported prostheses. A systematic review and meta-analysis. J Dent, 70, 14-22.

Maeda, Y., Satoh, T., \& Sogo, M. (2006). In vitro differences of stress concentrations for internal and external hex implant-abutment connections: a short communication. J Oral Rehabil, 33, 75-8.

Nentwig, G. H. (2004). Ankylos implant system: concept and clinical application. J Oral Implantol, 30, 171-7.

Nishioka, R. S., de Vasconcellos, L. G. O., \& Nishioka, G. N. M. (2011). Comparative strain gauge analysis of external and internal hexagon, Morse taper, and influence of straight and offset implant configuration. Implant Dent, 20, 24-32.

Ozcelik, T., \& Ersoy, A. E. (2007). An investigation of tooth/implant-supported fixed prosthesis designs with two different stress analysis methods: an in vitro study. J Prosthodont, 16, 107-16.

Palmer R. M., Palmer P. J., \& Smith, B. J. (1997). A prospective study of Astra single tooth implants. Clinical Oral Implants Research, 8(3), $173-179$.

Pesqueira, A. A., Goiato, M. C., Gennarri-Filho, H., Monteiro, D. R., dos Santos, D. M., Haddad, M. F., \& Pellizzer, E. P. (2014). Use of stress analysis methods to evaluate the biomechanics of oral rehabilitation with implants. Journal of Oral Implantology, 40(2), 217-228.

Pessoa, R. S., Muraru, L., Júnior, E. M., Vaz, L. G., Sloten, J. V. , Duyck, J., \& Jaecques S. V. N. (2010). Influence of implant connection type on the biomechanical environment of immediately placed implants-CT-based nonlinear, three-dimensional finite element analysis, 12(3), $219-34$.

Pessoa, R. S., Sousa, R. M., Pereira, L. M., Neves, F. D., Bezerra, F. J. B., Jaecques, S. V. N., loten, J. V., Quirynen, M., Teughels, W., \& Spin-Neto R. (2017). Bone remodeling around implants with external hexagon and morse-taper connections: a randomized, controlled, split-mouth, clinical trial. Clinical implant dentistry and related research, 19(1), 97-110.

Schmitt, C. M., Nogueira-Filho, G., Tenenbaum, H. C., Lai, J. Y., Brito, C., Doring, H., \& Nonhoff, J. (2014). Performance of conical abutment (Morse Taper) connection implants: a systematic review. J Biomed Mater Res, 102, 552-74.

Yamaguchi, S., Yamanishi, Y., Machado, L. S., Matsumoto, S., Tovar, N., Coelho, P. G., Thompson, V. P., \& Imazato, S. (2017). In vitro fatigue tests and in silico finite element analysis of dental implants with different fixture/abutment joint types using computer-aided design models. J Prosthodont Res, 62(1), 24-30.

Zaparolli, D., Peixoto, R. F., Pupim, D., Macedo, A. P., Toniollo, M. B., \& Mattos, M. G. C. (2017). Photoelastic analysis of mandibular full-arch implant-supported fixed dentures made with different bar materials and manufacturing techniques. Mater Sci Eng C Mater Biol Appl, 81, 144-7. 